\title{
Spillover Effects of Foreign Bank Entry in China's Banking Sector
}

\author{
Yuhua $\mathrm{Li}^{1}$, Tongsheng $\mathrm{Xu}^{1} \&$ Honglin Yuan ${ }^{1}$ \\ ${ }^{1}$ School of International Trade and Economics, Jiangxi University of Finance and Economics, Nanchang, China \\ Correspondence: Yuhua Li, School of International Trade and Economics, Jiangxi University of Finance and \\ Economics, and the Researcher of Jiahede-Jiangxi University of Finance and Economics Postdoctoral Innovation \\ Practical Base, Nanchang, 330013, China. Tel: 86-791-8381-6581. E-mail: yuhuali28@ gmail.com
}

Received: October 18, 2014

Accepted: November 24, 2014

Online Published: December 25, 2014

doi:10.5539/ibr.v8n1p156

URL: http://dx.doi.org/10.5539/ibr.v8n1p156

\begin{abstract}
This paper examines the foreign financial institutions' spillover effects in China's banking sector through three channels, foreign strategic investment, employee turnover, and competition using qualitative analyses and quantitative analyses. Through comparing Chinese banks performance between pre- and post- foreign strategic investment, and the OLS regression analyses, we found that the foreign strategic investment did benefit Chinese banks, but the impact of strategic investment is not very obvious. Employee turnover gives Chinese banks opportunity to learn from foreign banks, but the employee mobility from Chinese banks to foreign banks benefit foreign banks more. Although Chinese banking sector is open to foreign banks, the growth of foreign banks in China is restricted, and the competition effects are not very obvious.
\end{abstract}

Keywords: spillover effects, strategic investment, employee turnover, competition effect, information

\section{Introduction}

Several studies show evidence that in emerging countries foreign banks are more efficient than domestic banks and their entry and investments play a key role in the banking sector (Berger et al., 2009; Bhattacharya et al., 1997; Bonin et al., 2005a, 2005b; Claessens et al., 2001; Denizer, 2000; Goldberg et al., 2000; Goldberg and Saunders, 1981; Levine, 1996; Walter \& Gray, 1983; Weill, 2003). However, few studies examine how foreign banks affect the emerging countries' domestic banks, especially the relative empirical studies on the spillover effects.

China's economy has been growing about $10 \%$ per year in real terms over the last decade, and is projected by some to become the world's largest economy in the coming decades. This rapid growth maybe largely linked to the globalization of trade, but China has yet to "globalize" its banking sector. The China's banking sector is the most important component of the financial system, but it still remains undercapitalized, unprofitable, low efficiency, and saddled with non-performing loans (NPLs) mainly as a result of the entrenched relations between state-owned enterprises and banks while the country was moving from a planned to a market economy. Therefore, a series of bank reform is implemented to improve the competitiveness of Chinese banks. Encompassed in this reform, opening up of China's banking sector to foreign banks is one important decision. Chinese banking regulators hope this policy could improve the efficiency and competitive of Chinese banks through the spillover effects.

Previous studies examine the impact of foreign bank entry on Chinese banks (Laurenceson \& Qin, 2008; García-Herrero \& Santabárbara, 2008; Berger et al., 2009; Shen et al., 2009; Yuan \& Gunji, 2009). These studies have different results, García-Herrero \& Santabárbara (2008) and Berger et al. (2009) found positive and significant impact of foreign bank entry. Shen et al. (2009), Laurenceson \& Qin (2008), and Yuan \& Gunji (2009) found no impact or small impact of the foreign entry. However, few papers examine how foreign banks affect Chinese banks. Therefore, this study examines what are the channels of foreign banks' spillover effects in China's banking sector and gives the relative empirical evidence or anecdotal evidence to support the channels.

The remainder of this paper is as follows. Section 2 reviews the relative literature on spillover effects in banking sector FDI. The China's banking sector characteristic and development of foreign bank in China is discussed in section 3. Section 4 gives the three channels of the spillover effects in China's banking sector. Section 5 concludes. 


\section{Spillover Effects in Banking Sector FDI}

In banking sector, few studies focus on the channels of spillover effects of foreign bank entry. In the few studies, Lensink \& Hermes (2004) argue that foreign bank may affect domestic banks through competition effect, demonstration effect, and increasing the quality of human capital of domestic banks.

(1) Competition effect. The presence of foreign banks may stimulate domestic banks to reduce costs, increase efficiency and increased the diversity of financial services through competition. The pressure of increased competition gives the managers the incentive to perform in order to survive. Increased competition may lead to lower operating cost, interest rate margins, and profits (Hermes \& Lensink, 2001).

(2) Demonstration effect. The introduction of these services may stimulate domestic banks to develop such new services, improving the efficiency of financial intermediation of the domestic financial system. Moreover, foreign banks may also introduce modern and more efficient banking techniques that are new to domestic banks. These modern banking techniques may be copied (Lensink \& Hermes, 2004).

(3) Employee turnover. Foreign entry can have significant influence on human capital formation for domestic banking sectors. The influence can be achieved in three ways (Konopielko, 1999; Lensink \& Hermes, 2004; Mathieson \& Roldos, 2000). First, foreign banks become "salary leaders" to attract highly qualified specialists available. Second, foreign banks supplement the staffs with expatriate personnel at the beginning of entry. Third, foreign banks invest in training programs for new employees, including local employees. With labor turnover, local employees/bankers would have a chance to learn from the foreign managers and the training programs, assimilate the practices, and retain the skills when they move back to domestic banks (Mathieson \& Roldos, 2000). Improved human capital will reduce operation costs and contribute to more efficient banking practices.

These previous studies on spillover effects in banking sector mainly focus on literature reviewer theoretical arguments; however, few of these studies give the empirical evidence or anecdotal evidence to support their arguments. In addition, since the banking sector is the highly regulated industry and different liberalization degree in the foreign bank entry, the entry mode of foreign banks in a host country may be different according to different countries, so the channels of how foreign banks affect host countries' banks vary according to different countries' banking sector.

\section{Background on Foreign Bank Entry}

Since 1980, the Chinese banking sector has gone through four stages in its foreign entry process, and the development trend of foreign banks can be seen from Figure 1.

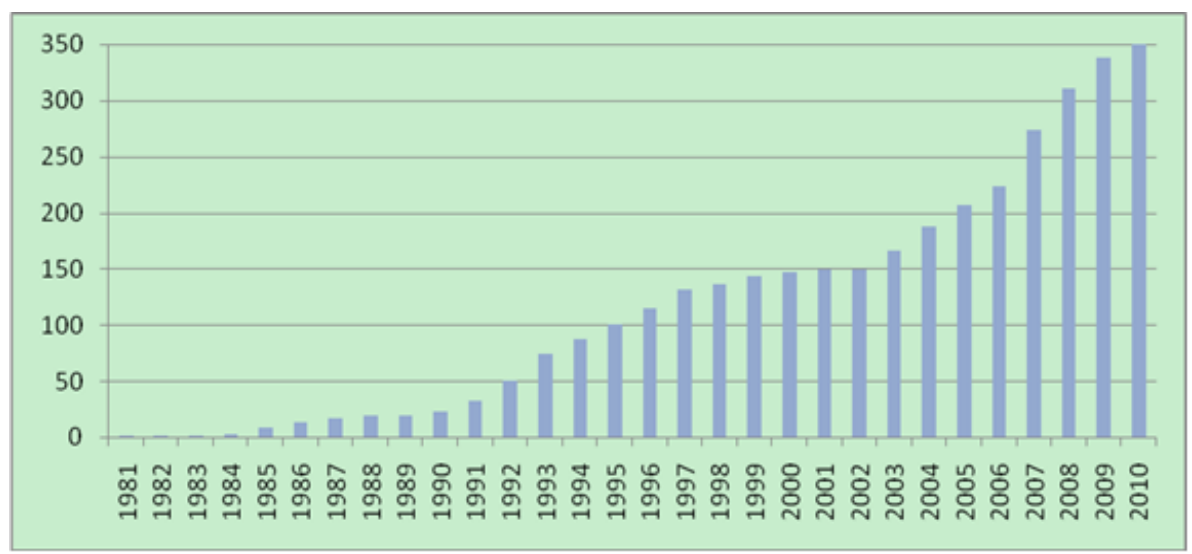

Figure 1. Foreign banks in China over 1980-2010

Source: Complied by the author according to the 2006 Report of the Almanac of China Finance and Banking and the 2010 Annual Report of CBRC.

Note: The foreign banks include the branches, sub-branches, foreign-owned subsidiaries.

Stage 1: Starting stage (1981-1990). In 1981, Nanyang Commercial Bank established a branch in Shenzhen, becoming the first foreign bank doing business in China since 1949. Foreign banks can only engage in exchange business in firms with three kinds of capital and foreign individuals. At the end of 1990, there are 22 branches and sub-branches of foreign banks and 1 subsidiary. Stage 2: Rapid development period (1991-1997). In the 
early 1990s, it was the fastest-growing period in foreign trade and foreign direct investment. The big demand for foreign financing is a good opportunity for the development of foreign banks. As of end-1997, the number of branches, sub-branches, and subsidiary of foreign banks in China reached 109. Stage 3: Contraction period (1998-2000). In the aftermath of Asian Financial Crisis, foreign banks became more cautious in expanding their business in the Asia-Pacific region, and foreign banks' business in China's banking sector also slowed down. From 1998 to 2001, only 15 new branches and sub-branches were established in China. Stage 4: New development (2001-now). On 11 December 2001, China gained accession to the WTO. The gradual deregulation on foreign banks enabled a rapid expansion of their business. In the five years following the WTO accession, the branches, sub-branches, and subsidiary of foreign banks expanded from 147 in 2001 to 291 in 2006. In addition, foreign banks are encouraged to set up strategic investment with Chinese banks.

\section{Channels of Spillovers Effects}

In China's banking sector, foreign banks affect Chinese banks mainly through strategic investment, employee turnover, and competition.

\subsection{Foreign Strategic Investment}

In China, there are 26 Chinese banks, which introduced foreign strategic investment from foreign banks during 2001-2008. It includes 4 state-owned commercial banks (SOCBs), 9 joint-stock commercial banks (JOCBs), 11 city commercial banks (CCBs), and 2 rural commercial banks (RCBs). The performance data over period 1998-2009 of these banks are mainly from Bankscope, the missing data of Bankscope is from the investor relations materials of each bank's official website and the Almanac of China Finance and Banking, and some are calculated by the author according to original data. Information about the foreign strategic investment is collected by the authors from media, each bank's Annual Report, and some literatures (see García-Herrero \& Santabárbara, 2008; Zhu et al., 2008).

In order to examine the impact of foreign strategic investment on Chinese banks, firstly, this study uses Chinese banks without strategic investment as matching group banks to investigate adjusted performance of Chinese banks which have introduced foreign strategic investment. The average value of performance of the matching group banks will be computed at every year ${ }^{1}$, and then this study gets the adjusted performance of Chinese banks by the raw value of Chinese banks minus the value of matching group banks. Secondly, this study wants to know whether performance of Chinese banks has been changed after introducing foreign strategic investment from foreign banks. So, this study compares the adjusted performance of Chinese banks between pre 3 years and post 3 years of introducing foreign strategic investment. Then, this study could get the difference of raw value and adjusted value of performance between pre 3 and post 3 years. Thirdly, this study aims to understand whether foreign strategic investment has any relevant impact on the performance of Chinese banks. The OLS model is used to examine the impact.

Performance of Chinese banks is measured by return on asset (ROA) and cost to income ratio (COSTR). For OLS model, the independent variable is Dstrategic, a dummy variable, if the Chinese bank has introduced strategic investment at year $t$ it is 1 , otherwise it is 0 . The control variables include macroeconomic variables, bank individual variables, and time variables. Macroeconomic control variables include GDP growth rate (GDPG) and interest rate on lending $(I R)$. Bank individual variables include Lnasset, state-owned commercial bank (SOCB), joint-stock commercial bank (JOCB), city commercial bank $(C C B)$ and LIST. Lnasset controls the impact of bank scale. $S O C B, J O C B$, and $C C B$ are dummy variables which are used to control bank type. Because banks with different type might reap different benefit from the fact that, for example, government regulations and policies might differ between different types of Chinese banks and this might impact on their performance. LIST is used as a dummy variable to capture the fact that listed companies might reap efficiency benefits from better corporate governance (Laurenceson et al., 2008). Time variables are the year variables, which are dummy variables and are used to control the difference of Chinese banks between different years.

Table 1 lists the comparison results between pre- and post-foreign strategic investment. The difference on raw value of $R O A$ between pre and post- foreign strategic investment is positive and significant at the 5 years period and 7 years period, which indicates that the profitability of Chinese banks increases after introducing foreign strategic investment from foreign banks. However, the difference on Adj_ROA is negative during the 3 periods, which indicates that the profitability of Chinese banks is smaller than that of matching group banks, but it is also not significant. The difference on raw value of COSTR between pre- and post- foreign strategic investment is negative and significant at the 3 periods, which indicates that the cost to income ratio of Chinese banks is improved after introducing foreign strategic investment. Also, the similar results can be seen from the difference on Adj_COSTR, which indicates that the cost to income ratio of Chinese banks with strategic investment is 
smaller than that of matching group banks.

Table 1. Comparison on performance between pre- and post-strategic investment

\begin{tabular}{|c|c|c|c|c|c|c|c|}
\hline & & \multicolumn{3}{|c|}{ Raw } & \multicolumn{3}{|c|}{ Adjusted } \\
\hline & & $Y_{-1}$ to $Y_{t+1}$ & $\mathrm{Y}_{-2}$ to $\mathrm{Y}_{\mathrm{t}+2}$ & $\mathrm{Y}_{-3}$ to $\mathrm{Y}_{\mathrm{t}+3}$ & $\mathrm{Y}_{-1}$ to $\mathrm{Y}_{\mathrm{t}+1}$ & $\mathrm{Y}_{-2}$ to $_{\mathrm{t}+2}$ & $\mathrm{Y}_{-3}$ to $\mathrm{Y}_{\mathrm{t}+3}$ \\
\hline \multirow{4}{*}{$R O A$} & Pre- & $0.559(19)$ & $0.559(36)$ & $0.538(50)$ & $0.225(19)$ & $0.260(36)$ & $0.256(50)$ \\
\hline & Post- & $0.772(19)$ & $0.859(35)$ & $0.878(51)$ & 0.188 (19) & $0.229(35)$ & $0.217(51)$ \\
\hline & difference & 0.213 & $0.300 * * *$ & $0.340^{* * *}$ & -0.037 & -0.030 & -0.039 \\
\hline & t-statistics & 1.641 & 3.082 & 4.438 & -0.294 & -0.333 & -0.528 \\
\hline \multirow{4}{*}{ COSTR } & Pre- & 45.265 (19) & $46.876(36)$ & $49.513(50)$ & $11.746(19)$ & $13.126(36)$ & $15.768(50)$ \\
\hline & Post- & 38.306 (19) & $37.929(35)$ & $37.862(51)$ & $6.495(19)$ & $6.808(35)$ & $7.423(51)$ \\
\hline & difference & $-6.959 * * *$ & $-8.948 * * *$ & $-11.651 * * *$ & $-5.252 * *$ & $-6.318 * * *$ & $-8.345^{* * *}$ \\
\hline & t-statistics & -3.030 & -4.993 & -6.593 & -2.413 & -3.644 & -4.693 \\
\hline
\end{tabular}

Source: compiled by the authors.

Note: It compares the mean value of these indicators. The value in the parentless is the observation. ***, **, and * indicate significance at $1 \%, 5 \%$, and $10 \%$ level respectively. ROA, return on assets; COSTR, cost to income ratio.

Table 2 lists the impact of foreign strategic investment on performance of Chinese banks. The coefficient of $A d j_{-} R O A$ is negative but not significant. And the coefficient of Adj_COSTR is negative and significant at $10 \%$ level which means that the cost to income ratio of Chinese banks with strategic investment is lower than the matching group banks. These results indicate that the strategic investments have improved some aspects of Chinese banks, but the degree of improvement is not very big. Comparing with previous studies, the results are consistent with the study of Yuan \& Gunji (2009) and Tan (2009).

Table 2. Impact of foreign strategic investment on performance of Chinese banks

\begin{tabular}{|c|c|c|c|c|}
\hline & Adj_ROA & & Adj_COSTR & \\
\hline & coefficient & t-statistics & coefficient & t-statistics \\
\hline Dstrategic & -0.017 & -0.23 & $-4.551 *$ & -1.93 \\
\hline GDPG & $-0.231 * * *$ & -3.32 & 1.313 & -0.76 \\
\hline IR & $0.521 * * *$ & -3.09 & -6.062 & -1.50 \\
\hline Lnasset & $0.210^{* * *}$ & -3.36 & $-6.735^{* * * *}$ & -3.11 \\
\hline SOCB & $-0.479 *$ & -1.74 & $11.598^{* *}$ & -2.09 \\
\hline JOCB & $-0.604 * *$ & -2.40 & $10.026^{* *}$ & -2.18 \\
\hline $\mathrm{CCB}$ & -0.137 & -0.56 & -0.441 & -0.11 \\
\hline LIST & $0.115^{* *}$ & -2.1 & -1.847 & -1.14 \\
\hline Cons & $-2.561 * * *$ & -3.02 & $109.958^{* * *}$ & -4.16 \\
\hline Obs. & \multicolumn{2}{|c|}{178} & \multicolumn{2}{|c|}{178} \\
\hline $\mathrm{R} 2$ & \multicolumn{2}{|c|}{0.253} & \multicolumn{2}{|c|}{0.448} \\
\hline
\end{tabular}

Source: Compiled by the authors.

Note: T-statistics are reported in the parentless. ***, **, and * indicate significance at $1 \%, 5 \%$, and $10 \%$ level respectively. Adj_ROA, adjusted value of return on assets; $A d j \_C O S T R$, adjusted value of cost to income ratio. Obs, number of observations. Value of year dummy variables is omitted. 


\subsection{Employee Turnover}

There are several characteristics of employee turnover between foreign banks and Chinese banks. First, some high qualified specialist move from foreign banks to Chinese banks which benefit Chinese banks at acquiring specific banking knowledge. For example, the personnel with risk management experience transferred from the foreign banks to the Chinese banks (Price Water House Cooper, 2009 report). Second, the movement of senior managers is in both sides. Some senior managers move from foreign banks to Chinese banks. For example, the previous CEO of Asia-Pacific region of Destuche Bank, Hongli Zhang, now is the vice president of Industrial \& Commercial Bank of China ${ }^{2}$. And some senior managers move from Chinese banks to foreign banks. For example, the board secretary of China Construction Bank, Changneng Yi, moved to an equity investment company, J.C. Flowers \& Co. LLC ${ }^{3}$; the manager of investment of China Construction Bank, Long Zhang, moved to a private equity investment company ${ }^{4}$.

Third, the negative spillover effect is more severe than positive spillover effect on the employee turnover. Table 3 lists the staff with foreign study/work experience in foreign banks and Chinese banks. Chinese banks have 9.97 percent staff with foreign study experience and 5.08 percent staff with foreign work experience. Obviously, Chinese banks have few staff with foreign work/study experience than foreign banks.

Table 3. Staff distribution between foreign banks and Chinese banks

\begin{tabular}{lcccc}
\hline & \multicolumn{2}{c}{ Foreign banks } & \multicolumn{2}{c}{ Chinese banks } \\
\cline { 2 - 5 } & Number & Percentage $(\%)$ & Number & Percentage $(\%)$ \\
\hline Foreign study experience & 1842 & 90.03 & 204 & 9.97 \\
Foreign work experience & 616 & 94.92 & 33 & 5.08 \\
\hline
\end{tabular}

Source: This report is got from the investigation of Shanghai Banking Association in 2008. This investigation involved 13 foreign banks, 12 Chinese banks.

Foreign banks not only have more staff with a foreign study/work experience, but also dig many staff from Chinese banks to replenish their staff due to the rapid growth of foreign banks. Many of these staffs come from state-owned commercial banks, and few staff is from joint-stock owned commercial banks and city commercial banks. It also can be reflected by the high turnover rate of Chinese banks, a survey has reported that $25 \%$ Chinese banks have high turnover rate in 2009 (China banker survey, 2009). In addition, the expatriate personnel and customer client managers are the favorite staff they would like to dig. Above all, the employee turnover, especially the senior managers and high qualified specialist in banking sector, does benefit Chinese banks, but it benefits foreign banks more.

\subsection{Competition}

From the number and asset scale of foreign banks, it gives an impression about the competition degree between foreign banks and Chinese banks. Figure 2 shows the absolute asset value of foreign banks and the ratio of foreign assets divided by total banking asset from 2003. Although the foreign bank asset ratio increases a lot from 2003 until 2007, the foreign asset ratio still less than 2.5\%. Comparing with other countries ${ }^{5}$, this ratio is extremely very low. The low foreign asset ratio indicates that the competition foreign banks bring to Chinese banks is very small.

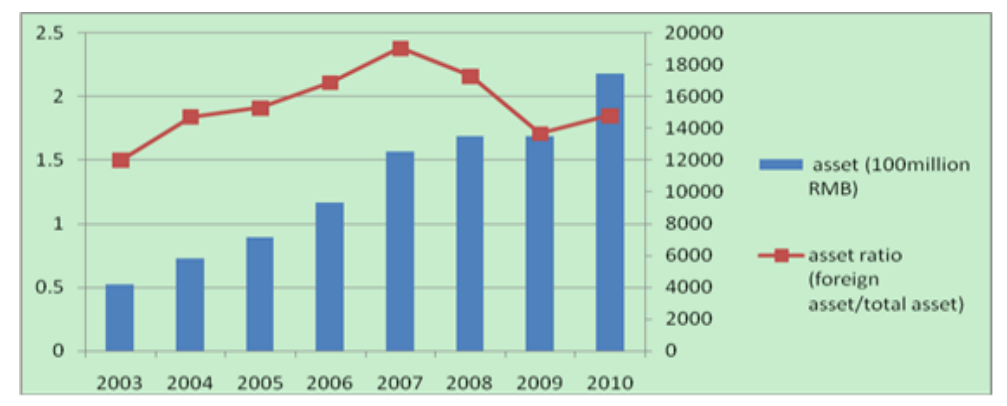

Figure 2. Asset of foreign banks in China's banking sector 
Although foreign banks couldn't compete with Chinese banks in the whole, in some specific business, e.g. trade finance and private banking business, foreign banks have the absolute competitive advantage which gives large pressure on Chinese banks and stimulate Chinese banks to improve their knowledge on it. In conclusion, the competition from foreign banks is not very severe in the whole, but in some specific business, foreign banks give large pressure to Chinese banks.

\section{Conclusions}

The impact of foreign bank entry into emerging countries is an interesting research topic. This paper examines the spillover effects in China's banking sector through three channels, foreign strategic investment, employee turnover, and competition. The foreign strategic investment did benefit Chinese banks, but the impact of strategic investment is not very obvious. Employee turnover gives Chinese banks opportunity to learn from foreign banks, but the employee mobility from Chinese banks to foreign banks benefit foreign banks more. The growth of foreign banks in China is restricted, and the competition effects from foreign financial institutions are not very obvious.

With respect to further work, more data investigation about employee turnover between Chinese banks and foreign banks should be conducted, for example, questionnaire or interview on the knowledge transfer with employee turnover. Moreover, with respect to competition between foreign banks and Chinese banks, more investigation towards Chinese sides and foreign sides is needed.

\section{Acknowledgments}

This paper has been financially supported by National Natural Science Foundation of China (71263016, 71363016), Jiangxi Province Social Science Twelve Five Project (13YJ09), China Postdoctoral Science Foundation (2014M551850), Jiangxi Postdoctoral Science Foundation (2014KY57).

\section{References}

Berger, A. N., Hasan, I., \& Zhou, M. (2009). Bank ownership and efficiency in China: What will happen in the world's largest nation? Journal of Banking and Finance, 33(1), 113-130. http://dx.doi.org/10.1016/j.jbankfin.2007.05.016

Bhattacharya, A., Lovell, C. A. K., \& Sahay, P. (1997). The impact of liberalization on the productive efficiency of Indian commercial banks. European Journal of Operational Research, 98(2), 332-345. http://dx.doi.org/10.1016/S0377-2217(96)00351-7

Bonin, J. P., Hassan, I., \& Wachtel, P. (2005). Bank performance, efficiency and ownership in transition countries.Journal of Banking and Finance, 29(1), 31-53. http://dx.doi.org/10.1016/j.jbankfin.2004.06.015

Bonin, J. P., Hassan, I., \& Wachtel, P. (2005). Privatization matters: Bank efficient in transition countries. Journal of Banking and Finance, 29(8-9), 2155-2178. http://dx.doi.org/10.1016/j.jbankfin.2005.03.012

Claessens, S., Demirgüç-Kunt, A., \& Huizinga, H. (2001). How does foreign entry affect domestic banking markets? Journal of Banking and Finance, 25(5), 891-911. http://dx.doi.org/10.1016/S0378-4266(00)00102-3

Denizer, C. (2000). Foreign entry in Turkey's banking sector, 1980-1997. In Claessens, S. \& Jansen, M. (Eds.), The Internationalization of Financial Services: Issues and Lessons for Developing Countries (pp. 389-406). Boston: Kluwer Academic.

García-Herrero, A., \& Santabárbara, D. (2008). Does the Chinese banking system benefit from foreign investors. BOFIT Discussion Papers, 11.

Goldberg, L. G., \& Saunders, A. (1981). The determinants of foreign banking activity in the US. Journal of Banking and Finance, 5(1), 17-32. http://dx.doi.org/10.1016/0378-4266(81)90005-4

Goldberg, L. S. (2004). Financial-sector FDI and host countries: New and old lessons. National Bureau of Economic Research Cambridge, Mass, USA. http://dx.doi.org/10.3386/w10441

Goldberg, L. S., Dages, B. G., \& Kinney, D. (2000). Foreign and domestic bank participation in emerging markets: lessons from Mexico and Argentina. NBER working paper.

Hermes, N. \& Lensink, R. (2001). Changing the conditions for development aid: A new paradigm. Journal of Development Studies, 37(6), 1-16. http://dx.doi.org/10.1080/713601080

Konopielko, L. (1999). Foreign Banks' Entry into Central and East European Markets: Motives and Activities. Post-Communist Economies, 11(4), 463-485. http://dx.doi.org/10.1080/14631379995841 
Laurenceson, J., \& Qin, F. (2008). Has minority foreign investment in China's banks improved their cost efficiency? China and World Economy, 16(3), 57-74. http://dx.doi.org/10.1111/j.1749-124X.2008.00114.x

Lensink, R., \& Hermes, N. (2004). The short-term effects of foreign bank entry on domestic bank behavior: Does economic development matter? Journal of Banking \& Finance, 28(3), 553-568. http://dx.doi.org/10.1016/S0378-4266(02)00393-X

Levine, R. (1996). Foreign banks, financial development, and economic growth, In Barfield, C. E. (Ed.), International financial markets: Harmonization versus competition (pp. 224-254). Washington, D.C.: American Enterprise Institute Press.

Mathieson, D. J., \& Roldos, J. (2001). Foreign banks in emerging markets. In Litan, R. \& Masson, P. \& Pomerleano, M. (Eds.), Open doors: Foreign participation in financial systems in developing countries, Brookings Institution Press.

Shen, C., Lu, C., \& Wu, M. (2009). Impact of foreign bank entry on the performance of Chinese banks. China \& World Economy, 17(3), 102-121. http://dx.doi.org/10.1111/j.1749-124X.2009.01153.x

Tan, M. N. T. (2009). Foreign investments in China's local banking sector - the Australian Experience. China Economic Journal, 2, 209-217. http://dx.doi.org/10.1080/17538960903083525

Walter, I., \& Gray, H. P. (1983). Protectionism, and international banking: Sectorial efficiency, competitive structure and national policy. Journal of Banking and Finance, 7(4), 597-609. http://dx.doi.org/10.1016/0378-4266(83)90019-5

Weill, L. (2003). Banking efficiency in transition economies. Economics of Transition, 11(3), 569-592. http://dx.doi.org/10.1111/1468-0351.00155

Yuan, Y., \& Gunji, H. (2009). The impact of foreign capital on the Chinese banking market. China Economic Journal, 2(3), 285-296. http://dx.doi.org/10.1080/17538960903529519

Zhu, Y., Zeng, Y., Li, P., \& He, J. (2008). Chinese banks attract overseas strategic investors: Background, arguments and comments. Management World, (1), 22-37 (in Chinese).

\section{Notes}

Note 1. For the 5 state-owned banks, 4 has introduced foreign strategic investors, it's not appropriate to find other type Chinese banks as their matching banks when we want to use the one-one matching approach. Therefore, this study uses one-many matching approach, which means that the average value of the banking industry is used as the matching value.

Note 2. Source: http://business.sohu.com/20100419/n271614582.shtml

Note 3. Source: http://www.21jrr.com/forum/viewthread.php?action=printable\&tid=12366

Note 4. Source: http://www.21jrr.com/forum/viewthread.php?action=printable\&tid=12366

Note 5. Claessens, S., Demirgüç-Kunt, A., \& Huizinga, H. (2001) give detail information of each country's foreign asset ratio.

\section{Copyrights}

Copyright for this article is retained by the author(s), with first publication rights granted to the journal.

This is an open-access article distributed under the terms and conditions of the Creative Commons Attribution license (http://creativecommons.org/licenses/by/3.0/). 